\title{
A Case of A 13-Year-Old Dog with Old Dog Encephalitis: A Rare Form of Canine Distemper
}

\author{
Erdem GÜLERSOY ${ }^{*}$, Mahmut OK$^{1}$, Mutlu SEVINÇ ${ }^{1}$, Murat Kaan DURGUT ${ }^{1}$, Amir NASER $\dot{I}^{1}$ \\ 'Selcuk University, Faculty of Veterinary Medicine, Department of Internal Medicine, 42003, Konya, TURKEY
}

\begin{abstract}
13 year-old male dog with complaints of fever, loss of appetite, stagnation as well as respiratory signs such as purulent nasal and eye discharge, cough and neurologic signs including apathy, ataxia, quadriplegia, muscular atrophy and myoclonus which admitted to the Animal Hospital of Faculty of Veterinary Medicine of Selcuk University. "Old dog encephalitis" was determined by clinical, laboratory examinations and rapid distemper test. Clinical findings revealed hyperthermia, tachypnea and tachycardia. Intravenous $0.9 \% \mathrm{NaCl}$ and $5 \%$ dextrose solution, vitamin and amino acids, ceftriaxone, n-acetylcysteine for improving clinical appearance and for controlling myoclonus pregabalin were used. In conclusion canine distemper virus may affect mature dogs over six years old as "old dog encephalitis" and this condition may provide a valuable model for further study of demyelinating diseases including measles in humans.
\end{abstract}

Keywords: Canine Distemper, Demyelination, Encephalitis, Old Dog

\section{Yaşlı Bir Köpekte “Old Dog Ensefalit” Olgusu: Köpek Distemper’ının Ender Formu}

\section{ÖZ}

13 yaşlı erkek bir köpek ateş, iştahsızlık, durgunluk gibi genel; purulent burun ve gözyaşı akıntısı, öksürük gibi respiratorik; apati, ataksi, kuadripleji, kas atrofisi ve miyoklonus gibi nörolojik bulgular ile Selçuk Üniversitesi Veteriner Fakültesi Hayvan Hastanesine getirilmiştir. Klinik muayene, laboratuvar analizleri ve yapılan distemper hızlı kiti ile "old dog ensefalit" tespit edilmiştir. Klinik muayenede vücut 1sısı, solunum sayısı ve kalp ritminde artış belirlenmiştir. Tedavi olarak intravenöz $0.9 \% \mathrm{NaCl}$ ve $5 \%$ dekstroz solüsyonları, vitamin ve aminoasitler, seftriakson, $\mathrm{N}$-asetil sistein, miyoklonusu kontrol altına almak için pregabalin uygulanmıştır. Sonuç olarak köpeklerin distemper virüsünün 6 yaşından büyük erişkin köpekleri "old dog ensefalit" olarak etkileyebileceği ve bu durumun insanlarda kızamık dahil demiyelinizasyon hastalıklarının daha ileri çalışmaları için değerli bir model olabileceği kanısına varılmıstır.

Anahtar Kelimeler: Distemper, Demiyelinizasyon, Ensefalitis, Yaşlı Köpek

To cite this article: Gülersoy E. Ok. M. Sevinc M. Durgut M.K. Naseri A. A Case of A 13-Year-Old Dog with Old Dog Encephalitis: A Rare Form of Canine Distemper. Kocatepe Vet J. (2020) 13(2):224-227 


\section{INTRODUCTION}

Canine distemper is an infectious disease, which is closely related to measles virus, a single-stranded, non-segmented, enveloped, RNA virus in the Paramyxoviridae family and genus Morbillivirus, infects variety of species. Virus can be found in dogs, wild dogs, jackals, foxes, hyenas and also in wild cats but not in domestic cats. The domestic dog is the most effected species. Morbilliviruses are transmitted by aerosols to the upper respiratory tract and cause clinical symptoms such as cough, fever and serous nasal discharge, as well as gastrointestinal signs such as vomiting and diarrhea complicated by secondary bacterial infections. When the nervous system is affected by canine distemper virus (CDV) dullness, progressive weakness, ataxia, paraplegia or quadriplegia, myoclonus, tremor, incontinence, seizures, depression, circling, head pressing, and visual deficits can be observed (Martella et al. 2008).

Cordy (1942) described an encephalitis in mature dogs that was characterized pathologically by lymphomonocytic perivascular inflammatory cell infiltrates in the central nervous system (CNS) and intranuclear inclusion bodies in neurons. Since the original description by Cordy (1942), any other report for ODE has not published. Clinical appearance was described as ataxia, convulsions, and circling. In mature dogs, this type of progressive panencephalitis is defined as old dog encephalitis (ODE). This type of encephalitis has not been seen in young dogs (Lincoln et al. 1971). The rarity and unusual morphologic characteristics of ODE are interesting. Different hypotheses have been proposed to elucidate the pathogenesis and occurrence of ODE. In mature dogs over six years old, viral perseverance in the CNS after acute infection which is characterized by progressive inflammation of the grey matter in brain hemispheres may trigger old dog encephalitis (Carvalho et al. 2012).

Neurologic signs may also occur without gastrointestinal or respiratory findings. The brain lesions mostly seen in cerebellopontine angle. These brain lesions consist of multifocal demyelination areas and necrosis of the white matter. The relationship of this multifocal encephalitis to old dog encephalitis is still not explained (Vandevelde et al. 1980).

CDV-induced encephalitis can be described in four forms. These forms are; acute and severe encephalitis in young dogs, with multisystemic appearance, including neurological signs; chronic encephalitis in adult dogs, with possibility of common neurological findings; old dog encephalitis; and chronic, relapsing encephalitis, the latter with minor occurrence (Carvalho et al. 2012).

\section{Case History}

13 year-old male Anatolian shepherd dog presented with neurologic signs of depression and unsteady gait for a few months. Clinical examination revealed diarrhea, mucopurulent nasal and ocular discharge (Figure 1a), dispnea, fever $\left(39.8{ }^{\circ} \mathrm{C}\right.$ ) abnormal respiratory sounds, head tilt, tremors, muscle atrophy and myoclonus all over the patient's body (Figure 1b). During physical examination findings such as nystagmus, ear scratching, rubbing and rotating did not observed. Also because dog was reacting to the environmental sounds, deafness was not considered. To confirm CDV, rapid distemper test (ASAN Easy Test, Canine Distemper Virus Antigen Test, Cat. No. AM9125-K, Seoul, Korea, relative sensitivity: 97.96\%, relative specificity: $97.50 \%$ ) was applied according to the manufacturer's instructions (Figure 1c). Complete blood count, blood gases analysis and cerebrospinal fluid (CSF) analysis were performed and presented in Table 1 and 2, respectively. Before the collection of CSF, the dog was sedated with xylazine at $1 \mathrm{mg} / \mathrm{kg}$ dosage intramuscular injection. CSF was collected between the occipital bone and the atlas using 22 gauge, 1.5-inch spinal needles with a stylet as Tipold (2003) reported. Excessive flexion of the head to collect CSF was avoided to prevent obstruction of the airway.

For improving clinical appearance, intravenous $0.9 \%$ $\mathrm{NaCl}$ and 5\% dextrose solution, vitamin and amino acids, ceftriaxone at $25 \mathrm{mg} / \mathrm{kg}$ dosage and nacetylcysteine at $100 \mathrm{mg} / \mathrm{kg}$ dosage were used. For controlling myoclonus, head tilt and tremors pregabalin at $4 \mathrm{mg} / \mathrm{kg}$ dosage were used orally. Because the owner refused euthanasia we were unable to perform necropsy and add the necropsy findings to the report. After a few weeks it was learned from the owner that the euthanasia was made in another veterinary clinic due to worsening the clinical appearance. 


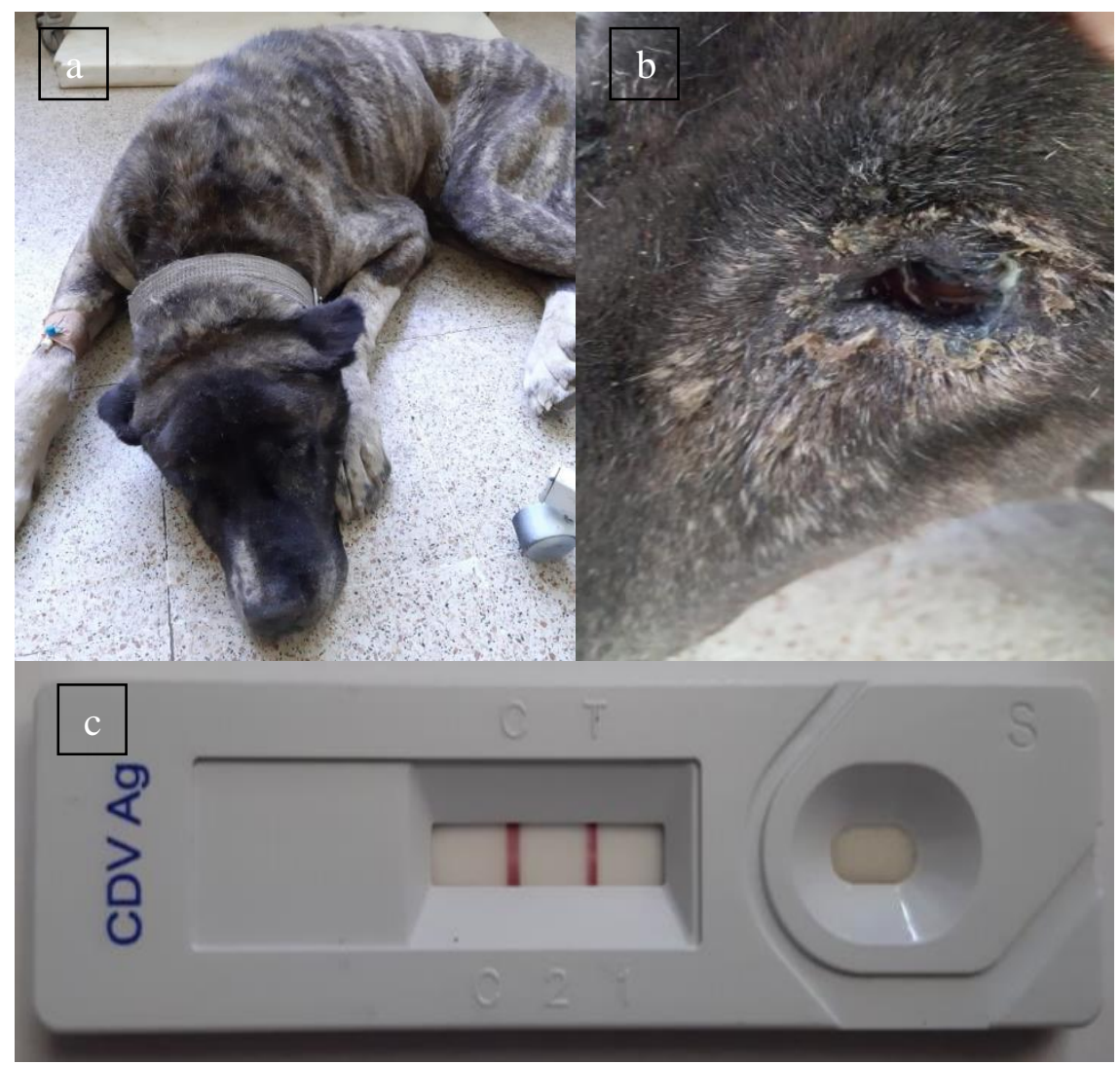

Figure 1.General appearance of the $\operatorname{dog}(\mathrm{a})$, purulent ocular discharge (b) and positive rapid distemper test (c).

Table 1. Blood gases analysis and CBC

\begin{tabular}{|c|c|c|c|c|c|}
\hline Blood Gases & & Range & Haemogram & & Range \\
\hline $\mathrm{pH}$ & 7.38 & $7.35-7.45$ & $\mathrm{WBC} \mathrm{m} / \mathrm{mm}^{3}$ & $26.53 \uparrow$ & $5.0-19.0$ \\
\hline $\mathrm{pCO}_{2} \mathrm{mmHg}$ & $30.3 \downarrow$ & $40-45$ & Lym \% & 20 & $5.0-30.0$ \\
\hline $\mathrm{pO}_{2} \mathrm{mmHg}$ & $26.2 \downarrow$ & $30-42$ & Mon $\%$ & 3.40 & $2.0-6.0$ \\
\hline $\mathrm{K} \mathrm{mmol} / \mathrm{L}$ & 3.9 & $3.4-5.6$ & Gra \% & 76.60 & $40.0-80.0$ \\
\hline $\mathrm{Na} \mathrm{mmol} / \mathrm{L}$ & $149 \downarrow$ & $150-165$ & $\operatorname{Lym} \# \mathrm{~m} / \mathrm{mm}^{3}$ & 5.30 & $0.2-5.7$ \\
\hline $\mathrm{Ca} \mathrm{mmol} / \mathrm{L}$ & $0.96 \downarrow$ & $2.0-2.7$ & Mon \# m/ mm³ & 0.90 & $0.1-1.1$ \\
\hline $\mathrm{Cl} \mathrm{mmol/L}$ & 114 & $104-128$ & Gra \# m/mm³ & $20.33 \uparrow$ & $2.0-15.2$ \\
\hline Glukoz mg/dL & $43 \downarrow$ & $64-170$ & $\mathrm{RBC} \mathrm{M} / \mathrm{mm}^{3}$ & $9.30 \uparrow$ & $4.0-9.0$ \\
\hline Lactate $\mathrm{mmol} / \mathrm{L}$ & $10 \uparrow$ & $0-2$ & MCV fl & $59.1 \uparrow$ & $35.5-55.0$ \\
\hline Hct $\%$ & $51.2 \uparrow$ & $29-48$ & Hct \% & $54.9 \uparrow$ & $24.0-45.0$ \\
\hline Base(ecf) $\mathrm{mmol} / \mathrm{L}$ & $-6.8 \uparrow$ & $-4-4$ & $\mathrm{MCH}$ pg & 18.4 & $16.0-24.0$ \\
\hline Base (B) $\mathrm{mmol} / \mathrm{L}$ & $-5.4 \uparrow$ & $-4-4$ & $\mathrm{MCHC} \mathrm{g} / \mathrm{dl}$ & 31.3 & $28.0-40.0$ \\
\hline HCO3 $(\mathrm{P}, \mathrm{st}) \mathrm{mmol} / \mathrm{L}$ & $18.8 \downarrow$ & $19-24$ & RDW & 10.7 & $8.0-12.0$ \\
\hline $\mathrm{HCO} 3$ (P) $\mathrm{mmol} / \mathrm{L}$ & $28.2 \downarrow$ & $19-24$ & THR \# m/ $\mathrm{mm}^{3}$ & 166 & $120-500$ \\
\hline
\end{tabular}

Table 2. Cerebrospinal fluid analysis

\begin{tabular}{lll}
\hline Analysis & Results & Range \\
\hline Leukocyte (cell/mm $\left.\mathbf{m m}^{3}\right)$ & - & $<5$ \\
Glucose $(\mathbf{m m o l} / \mathbf{L}) *$ & 2.8 & 35 \\
Protein $(\mathbf{m g} / \mathbf{d l})$ & - & $<30$ \\
Specific gravity & 1.015 & 1.005 \\
\hline
\end{tabular}

*\%60-80 concentration of blood glucose 


\section{DISCUSSION}

Canine distemper is an important viral disease which affects variety of species but mostly dogs in a multi systemic manner. At about 10 days post infection, CDV starts to spread from primer replication site which is the lymphoid tissue (Vandevelde and Zurbriggen 2005). In th body, CDV infects various cell types including epithelial, mesenchymal, hematopoietic, and neuroendocrine cells. Clinical findings include immunosuppression, respiratory and gastrointestinal signs, and demyelinating leukoencephalitis. CDV mediates the early destruction of the lymphocytes results in immunosuppression. Ezeibe and Udegbunam (2008) reported in dogs with distemper virus, leukopenia initially associated with lymphopenia and later lymphocytosis which leads to leucocytosis. In this case report, significant leukocytosis observed probably due to secondary bacterial infection. Also our haemogram findings were compatible as Ezeibe and Udegbunam (2008) reported.

In CNS, CDV causes severe demyelinating lesions. Cytokines such as interleukin 8, interleukin 10 and interferon gamma can be measured in CSF. But an elevation of cytokines levels in CSF are not specific for particular diseases. Nevertheless in the CSF of animals with acute myelin lesions high interleukin 8 titers can be found (Vandevelde and Zurbriggen 2005). In non-inflammatory distemper cases, protein and cell content of CSF may be in normal ranges. In this case report the results of CSF analysis were compatible as Tipold (2003) reported. Regardless of its cause, demyelination occurs thru two main processes: direct damage to the myelin itself or to myelinogenic cells which is described as primary demyelination or axonal injury. This type of injury promotes a secondary effect in the myelinic degeneration and referred to secondary demyelination (Carvalho et al. 2012). In addition, virus-induced microglial cell activation probably plays a role in demyelinating process (Vandevelde and Zurbriggen 2005). This neurologic disease is characterized by mental impairment and occurs mostly in middle aged dogs (Vandevelde et al. 1980). As the naturally occurring incidence of ODE is low and generally the cause is related to CDV, old dog encephalitis is a rare condition and a valuable model for severe demyelinating diseases of dogs and humans. Adams et al. (1975) indicate that to elucidate the mechanisms of demyelination diseases both in animals and humans, a cooperation of veterinarians and physicians is required. It is not possible to differentiate old dog encephalitis and multifocal distemper encephalitis by breed, sex or initial neurologic signs.

In conclusion, old dog encephalitis is a rare CDVinduced subacute neurologic disease affecting mature dogs over six years old and it would be a beneficial animal model for the further study of demyelinating diseases in humans including chronic progressive paramyxovirus infections as CDV closely related to measles virus.

Conflict of Interest: The authors declare that they have no conflict of interest.

\section{REFERANCES}

Adams JM, Brown WJ, Snow HD, Lincoln SD, Sears AW, Barenfus M, Holliday TA, Cremer NE, Lennette EH. Old Dog Encephalitis and Demyelinating Diseases in Man. Veterinary Pathology. 1975; 12: 220-226.

Carvalho OV, Botelho CV, Ferreira CGT, Scherer PO, Soares-Matins JAP, Almeida MR, Junior AS. Immunopathogenic and Neurologic Mechanisms of Canine Distemper Virus. Adv Virol. 2012; 2: 163860.

Ezeibe MCO, Udegbunam RI. Haematology of dogs infected with canine distemper virus. Sokoto J Vet Sci. 2008; 7 : 30-32.

Lincoln SD, Gorham JR, Hegreberh GA. Etiologic Studies of Old Dog Encephalitis. Veterinary Pathology. 1971; 8: 1-8.

Martella V, Elia G, Buonavoglia C. Canine distemper virus. Vet Clin Small Anim. 2008; 38:787-797.

Tipold A. Cerebrospinal Fluid. Clinical Neurology in Small Animals - Localization, Diagnosis and Treatment, K.G. Braund (Ed.) Publisher: International Veterinary Information Service. Ithaca, New York, USA. 2003.

Vandevelde M, Kristensen B, Braund KG, Greene CE, Swango LJ, Hoerlein BF. Chronic Canine Distemper Virus Encephalitis in Mature Dogs. Veterinary Pathology. 1980; 17: 17-29.

Vandevelde M, Zurbriggen A. Demyelination in canine distemper virus: a review. Acta Neuropathol. 2005; 109: 56-68. 